NOMENCLATURE

Edited by Gerry Moore, James Lendemer \& Erin Tripp

\title{
The correct names for species of Aloe sect. Chortolirion (Asphodelaceae: Alooideae)
}

\author{
Ronell R. Klopper, ${ }^{1,2}$ Gideon F. Smith, ${ }^{1,2,3}$ Estrela Figueiredo, ${ }^{3,4}$ Olwen M. Grace ${ }^{5,6}$ \\ \& Abraham E. van Wyk ${ }^{2}$ \\ 1 Biosystematics Research and Biodiversity Collections Division, South African National Biodiversity Institute, Private Bag X101, \\ Pretoria 0001, South Africa \\ 2 H.G.W.J. Schweickerdt Herbarium, Department of Plant Science, University of Pretoria, Pretoria 0002, South Africa \\ 3 Centre for Functional Ecology, Departamento de Ciências da Vida, Universidade de Coimbra, 3001-455 Coimbra, Portugal \\ 4 Department of Botany, P.O. Box 77000, Nelson Mandela Metropolitan University, Port Elizabeth 6031, South Africa \\ 5 Jodrell Laboratory, Royal Botanic Gardens, Kew, Surrey TW9 3DS, U.K. \\ 6 Botanic Garden \& Herbarium, Natural History Museum of Denmark, Sølvgade 83 Opg. S, 1307 Copenhagen K, Denmark \\ Author for correspondence: Ronell R.Klopper,r.klopper@sanbi.org.za
}

\begin{abstract}
The correct names and synonymy for species of Aloe sect. Chortolirion (A. Berger) Boatwr. \& J.C. Manning (Asphodelaceae: Alooideae) are provided. This treatment recognises four species in this section, namely A. welwitschii, A. barendii, A. jeppeae and A. subspicata. Aloe subspicata and A. welwitschii are treated as conspecific by some authors.
\end{abstract}

Keywords Aloe; Alooideae; Asphodelaceae; Chortolirion; Haworthia; synonymy

Received: 4 Apr. 2013; revision received: 29 Aug. 2013; accepted: 10 Sep. 2013. DOI: http://dx.doi.org/10.12705/626.5

\section{- INTRODUCTION}

Chortolirion A. Berger has a history of taxonomic uncertainty, and has been variously allied to Haworthia Duval and Aloe L. (Smith, 1991; Treutlein \& al., 2003). The vast majority of the contemporary published research on Aloe and Chortolirion, including several books and numerous papers, has been produced by participants of the Aloes of the World (AWP) project. Established in 2007, the AWP currently has over 40 members from around the world (Smith \& al., 2008a, b; Klopper \& al., 2010, 2013; Klopper \& Smith, 2013; Smith, 2013). This initiative provides a community for Aloe scholars, specialists and enthusiasts to collaborate and disseminate information on the genus and its kin, thus informing interested parties of research on subfamily Alooideae of the Asphodelaceae.

As part of ongoing research activities within the AWP, Grace \& al. (2013) recently transferred three species of Chortolirion to Aloe. Shortly afterwards, Daru \& al. (2013) similarly transferred species of Chortolirion to Aloe. Here we provide clarification on which names to use for these species in Aloe. The names proposed by two of us (R.R. Klopper and G.F. Smith) in Grace \& al. (2013) have priority (McNeill \& al., 2012, Art. 53.1), rendering two names published by J.S. Boatwright and J.C. Manning in Daru \& al. (2013) synonymous with those in Grace \& al. (2013).

\section{CORRECT NAMES FOR SPECIES OF ALOE sect. CHORTOLIRION}

1. Aloe welwitschii Klopper \& Gideon F. Sm. in Phytotaxa 76: 12. Jan $2013 \equiv$ Haworthia angolensis Baker in Trans. Linn. Soc. London, Bot. 1(5): 263. $1878 \equiv$ Chortolirion angolense (Baker) A. Berger in Engler, Pflanzenr. IV 38 (Heft 33): 73. 1908 - Holotype: ANGOLA. Huilla [Huíla] District: near Huilla [Huíla], flowered Nov. 1859, F.M.J. Welwitsch 3756 (BM No. BM000911693!).

Since the name Aloe angolensis Baker (in Trans. Linn. Soc. London, Bot. 1(5): 263. 1878) already exists, this combination is not available if Chortolirion angolensis is transferred to Aloe.

This rare species is restricted to the Huíla Plateau in Angola and we regard it as distinct from material that occurs in the Flora of Southern Africa region. Unlike Daru \& al. (2013), we accept $A$. welwitschii as distinct from $A$. subspicata (Baker) Boatwr. \& J.C. Manning.

2. Aloe barendii Klopper \& Gideon F. Sm. in Phytotaxa 76: 12. Jan $2013 \equiv$ Haworthia tenuifolia Engl. in Bot. Jahrb. Syst. 10: 2, t. 1. $1888 \equiv$ Chortolirion tenuifolium (Engl.) A. Berger in Engler, Pflanzenr. IV 38 (Heft 33): 73. $1908 \equiv$ Aloe tenuifolia (Engl.) Boatwr. \& J.C. Manning in Taxon 62: 75. Feb 2013, non Lam. 1783, nom. illeg. - Holotype: SOUTH AFRICA. Northern Cape: Kalahari Region, near Kuruman, R. Marloth 1049 (B No. B100165765 !; isotype: PRE No. PRE0037837-0!). 
Since the name Aloe tenuifolia Lam. (Encycl. 1(1): 87. 1783) already exists, this combination is not available if Chortolirion tenuifolium is transferred to Aloe. The new combination published in Daru \& al. (2013) is a later homonym and therefore illegitimate.

3. Aloe jeppeae Klopper \& Gideon F. Sm. in Phytotaxa 76: 12. Jan $2013 \equiv$ Chortolirion latifolium Zonn. \& G.P.J. Fritz in Bradleya 28: 32.2010 三Aloe aestivalis Boatwr. \& J.C. Manning in Taxon 62: 75. Feb 2013, nom. superfl., nom. illeg. - Holotype: SOUTH AFRICA. Free State: Bloemfontein near airport, 24 Apr. 2009, G.P.J. Fritz 1025 (PRE!).

Since the name Aloe latifolia (Haw.) Haw. (in J. Linn. Soc. Bot. 18: 164. 1880) already exists, this combination is not available if Chortolirion latifolium is transferred to Aloe. The replacement name, A. aestivalis, published in Daru \& al. (2013) is superfluous and illegitimate (Art. 52.1 in McNeill \& al., 2013).

4. Aloe subspicata (Baker) Boatwr. \& J.C. Manning in Taxon 62: 75. Feb $2013 \equiv$ Haworthia subspicata Baker in Bull. Herb. Boissier, ser. 2, 4: 998. $1904 \equiv$ Chortolirion subspicatum (Baker) A. Berger in Engler, Pflanzenr. IV 38 (Heft 33): 74. 1908 - Holotype: SOUTH AFRICA. Gauteng: Modderfontein, 9 Sep. 1897, P. Conrath 645 (Z No. Z000023936 !; isotype: K No. K000256772 !).

\section{口ACKNOWLEDGEMENTS}

We would like to thank the editor and an anonymous referee for suggesting improvements to the manuscript.

\section{口 LITERATURE CITED}

Daru, B.H., Manning, J.C., Boatwright, J.S., Maurin, O., Maclean, N., Schaefer, H., Kuzmina, M. \& Van der Bank, M. 2013. Molecular and morphological analysis of subfamily Alooideae (Asphodelaceae) and the inclusion of Chortolirion in Aloe. Taxon 62: $62-76$.
Grace, O.M., Klopper, R.R., Smith, G.F., Crouch, N.R., Figueiredo, E., Rønsted, N. \& Van Wyk, A.E. 2013. A revised generic classification for Aloe (Xanthorrhoeaceae subfam. Asphodeloideae). Phytotaxa 76: 7-14. http://dx.doi.org/10.11646/phytotaxa.76.1.2

Klopper, R.R \& Smith, G.F. 2013. Aloes of the World: When, where and who? Aloe 50: 44-52.

Klopper, R.R., Smith, G.F. \& Demissew, S. 2010. The Aloes of the World Project. Pp. 781-785 in: Van der Burgt, X., Van der Maesen, J. \& Onana, J.-M. (eds.), Systematics and conservation of African plants. Proceedings of the XVIIIth triannual Congress of the AETFAT, Yaoundé, Cameroon. London: Kew Publishing, Royal Botanic Gardens, Kew.

Klopper, R.R., Smith, G.F., Crouch, N.R., Grace, O.M. \& Demissew, S. 2013. Aloes of the World Project: Background and progress. Pp. 332-336 in: Beau, N., Dessein, S. \& Robbrecht, E. (eds.), African plant diversity, systematics and sustainable development. Proceedings of the XIXth AETFAT Congress, held at Antananarivo, Madagascar, 26-30 April 2010. Scripta Botanica Belgica 50. Meise: National Botanic Garden of Belgium.

McNeill, J., Barrie, F.R., Buck, W.R., Demoulin, V., Greuter, W., Hawksworth, D.L., Herendeen, P.S., Knapp, S., Marhold, K., Prado, J., Prud'homme van Reine, W.F., Smith, G.F., Wiersema, J.H. \& Turland, N.J. (eds.) 2012. International Code of Nomenclature for algae, fungi, and plants (Melbourne Code) adopted by the Eighteenth International Botanical Congress Melbourne, Australia, July 2011. Regnum Vegetabile 154. Königstein: Koeltz Scientific Books.

Smith, G.F. 1991. Historic review of the taxonomy of Chortolirion Berger (Asphodelaceae: Alooideae). Aloe 28: 90-95.

Smith, G.F. 2013. The fascinating world of aloes, a truly African flagship plant group. Aloe 50: 6 .

Smith, G.F., Walters, M., Crouch, N.R. \& Klopper, R.R. 2008a. Aloes of the World: A comprehensive collaboration to consolidate knowledge on the genus Aloe L. Aloe 45: 19-20.

Smith, G.F., Walters, M., Klopper, R.R. \& Crouch, N.R. 2008 b. Aloes of the World: African Plants Initiative. An international web-based collaboration to promote scholarly research on Aloe L. Bradleya 26: 121-128.

Treutlein, J., Smith, G.F., Van Wyk, B.-E. \& Wink, M. 2003. Phylogenetic relationships in Asphodelaceae (subfamily Alooideae) inferred from chloroplast DNA sequences ( $r b c L$, matK) and from genomic fingerprinting. Taxon 52: 193-207. http://dx.doi.org/10.2307/ $\overline{3647389}$ 